\title{
Ethnic aspects of vitamin D deficiency
}

\author{
Aspectos étnicos da deficiência de vitamina D
}

${ }^{1}$ Division of Endocrinology, Diabetes and Bone Diseases, Agamenon Magalhaes Hospital, Brazilian Ministry of Health, University of Pernambuco Medical School, Recife, PE, Brazil
Correspondence to: Francisco Bandeira

Disciplina de Endocrinologia

Faculdade de Ciências Médicas, Universidade de Pernambuco

Av. Rui Barbosa, 1435

52050-450 - Recife, PE, Brasil

fbandeira@gmail.com

Received on Feb/28/2014 Accepted on May/26/2014

DOI: 10.1590/0004-2730000003320
Aline Correia', Maria do Socorro Azevedo', Fernando Gondim', Francisco Bandeira'

\begin{abstract}
Vitamin D deficiency has been linked to bone fragility in children and adults, and to an increased risk of chronic diseases. The main sources of vitamin $D$ are the diet and cutaneous synthesis, the latter being the most important one, since foods are relatively poor in vitamin $\mathrm{D}$. The main factors influencing this endogenous production are the seasons, the time of day, latitude and skin phototype. Due to the contribution of sun exposure in maintaining vitamin $D$ levels, it would be expected that this deficiency would be more prevalent in countries at a high latitude; it has been shown, however, that hypovitaminosis $D$ is commonly found in tropical regions such as Brazil. In high latitude regions in which extreme skin phototypes have been compared, the prevalence of vitamin $\mathrm{D}$ deficiency is more common in people with originally darker skin who have a natural barrier to the already lower UV irradiation penetrating the skin. In Brazil, particularly in the areas where sun rays are more abundant, the difference in sunlight exposure between subjects showed no significant variation in serum 25-hydroxyvitamin D (25OHD). Arq Bras Endocrinol Metab. 2014;58(5):540-4
\end{abstract}

Keywords

Vitamin D deficiency; sun index; skin phototype; 250HD

\section{RESUMO}

A deficiência de vitamina $D$ tem sido associada à fragilidade óssea em crianças e adultos $e$ ao aumento do risco de doenças crônicas. As principais fontes de vitamina $D$ são a dieta e a síntese cutânea, sendo esta última a mais importante, uma vez que os alimentos são relativamente pobres em vitamina $\mathrm{D}$. Os principais fatores que influenciam essa produção endógena são as estações do ano, a hora do dia, a latitude e o fototipo de pele. Devido à contribuição da exposição solar em manter os níveis de vitamina $D$, seria de esperar que essa deficiência fosse mais prevalente nos países com alta latitude; no entanto, a hipovitaminose D é comumente encontrada em regiões tropicais como o Brasil. Em regiões de alta latitude em que os extremos de fototipos de pele foram comparados à prevalência de deficiência de vitamina $D$, é mais comum em pessoas com pele originalmente mais escura que têm uma barreira natural à já baixa penetração da irradiação UV na pele. No Brasil, particularmente nas áreas mais ensolaradas, a diferença de exposição solar entre os indivíduos não mostrou variação significativa nos níveis séricos de 25-hidroxivitamina D (25OHD). Arq Bras Endocrinol Metab. 2014;58(5):540-4

Descritores

Deficiência de vitamina D; índice solar; fototipo de pele; 250HD

\section{INTRODUCTION}

$\mathrm{V}$ itamin $\mathrm{D}$ deficiency has been associated with bone fragility in children and adults and an increased risk of chronic diseases such as cardiovascular diseases, diabetes mellitus type 1 and 2 and cancer (1). The sources of vitamin $\mathrm{D}$ are cutaneous production and diet; however, only some foods naturally contain it, and few are rich in vitamin D. In Brazil, diet is usually poor in vitamin $\mathrm{D}$ and supplementation with multivitamin preparations is rarely seen (2). Exposure to sunlight is the main source of vitamin D and factors such as season, time of day, latitude, skin phototype, sun exposure duration, type of clothing and the use of sunscreens may influence its synthesis (3). 
When the early humans, who originated in Africa, migrated northwards, skin lightening occurred, as an adaptation to the lower amount of ultraviolet irradiation required for the cutaneous synthesis of vitamin D (4). Melanin evolved as an effective natural sunscreen, decreasing the production of vitamin $\mathrm{D}$ in the skin, because of its capacity to absorb ultraviolet radiation (UVB) photons, as people with increased skin pigmentation require longer exposure to the sun for synthesizing the same amount of vitamin $\mathrm{D}$ than persons with fair skin (1). The differences in serum 25OHD levels between individuals of different ethnicities is based on the view that contemporary humans are genetically adapted to the environment of our ancestors and that the profound changes in lifestyle that have occurred over the last 10,000 years (including reduced sun exposure) have been too fast for the human genome to adjust to them (5).

The concept of skin phototype was described by Fitzpatrick (Table 1) about 3 decades ago, classifying individuals according not only to skin color, but also to the way in which they respond to repetitive sun exposure regarding melanin production (tanning) (6). Most studies to date have evaluated the differences between serum $25 \mathrm{OHD}$ concentrations in phototypes type I or II, compared to the darkest type (VI), claiming that less pigmented skin has higher concentrations due to its greater capacity to synthesize vitamin D (7).

Table 1. Classification of skin phototypes

\begin{tabular}{ll}
\hline Skin types & \multicolumn{1}{c}{ Description } \\
\hline Type I & Very fair skin, always burns and never tans \\
Type II & Fair skin, always burns and sometimes tans \\
Type III & Less fair skin, sometimes burns and always tans \\
Type IV & Light brown skin, rarely burns and always tans \\
Type V & Dark brown skin, never burns and always tans \\
Type VI & Dark skin, never burns and always tans \\
\hline
\end{tabular}

Adapted from Fitzpatrick TB, 1988.

Sun exposure may also be estimated using the sun index (number of hours per week of sun exposure multiplied by the fraction of the total body surface area exposed - using the rule of 9 adapted from the burning patient score) (8). There are few studies quantifying the response of serum $25 \mathrm{OHD}$ according to sun exposure and skin type (2).

At high latitudes serum 25OHD levels exhibit variability throughout the year, with a peak in late summer and a nadir in late winter, due to the variation in the UVB that reaches the skin (9). A paradox exists in countries with a low sun incidence, such as Norway $\left(60^{\circ} \mathrm{N}\right)$, which show a lower frequency of vitamin D deficiency (probably because of the diet), when compared to countries with a higher solar incidence, such as those of Mediterranean Europe. In the Middle East (lower latitudes) there is a high prevalence of vitamin $\mathrm{D}$ deficiency, which can be explained by the habitual use of clothing covering almost the entire body (9). These locations are usually in semiarid and arid areas with year-round sunshine and little rain throughout the year (Figures 1 and 2).

There is much debate concerning the ideal serum 25OHD concentrations. The Endocrine Society (10) recommends $30 \mathrm{ng} / \mathrm{mL}$ or above, with a parathyroid hormone plateau occurring between 30 and $40 \mathrm{ng} / \mathrm{mL}$; the Institute of Medicine (11), on the other hand, considers levels above $20 \mathrm{ng} / \mathrm{mL}$ to be appropriate for most individuals.

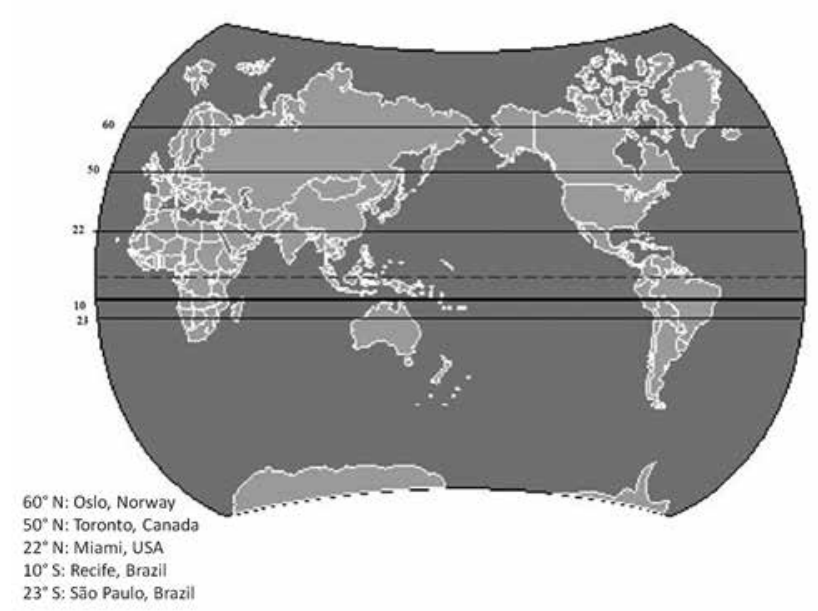

Figure 1. Northern and southern latitudes (in degrees). Adapted from Bandeira F, et al., 2006 (9).

\section{The tropics}

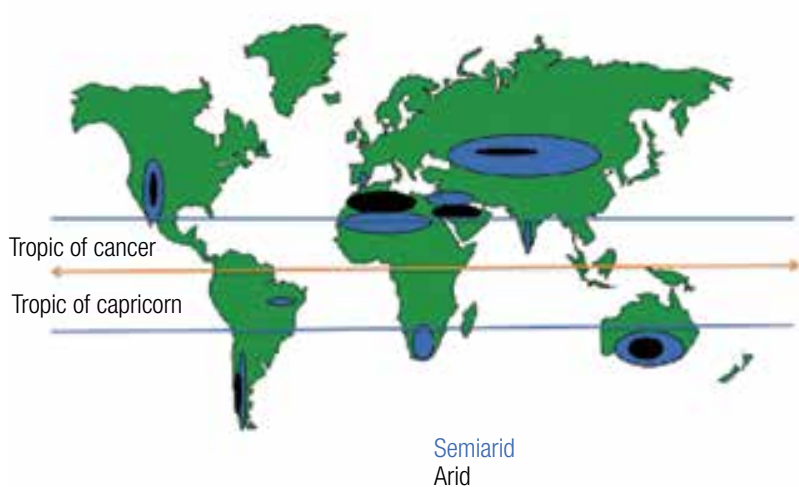

Figure 2. The tropics and semiarid and arid regions globally. Adapted from Bandeira and cols. 2006 (9). 
Based on the important contribution of sunlight exposure to the production and maintenance of serum 25OHD levels, it would be reasonable to believe that vitamin $\mathrm{D}$ deficiency may be a problem restricted to countries situated at higher latitudes. However, several studies from sunny countries have shown that vitamin D deficiency is a common phenomenon, despite the abundance of sunlight in these locations, such as Brazil, making it a global health problem (12-14).

\section{ETHNICITY AND VITAMIN D DEFICIENCY ABROAD}

Although some studies have found no differences in serum 25OHD levels between individuals with light skin and those with dark skin (15), others have reported lower levels being more common in people with dark skin than in fair-skinned individuals (16-18).

In a study on 503 volunteers (aged between 18 and 85 years) the association of ethnicity, skin color and sun exposure with serum levels of $25 \mathrm{OHD}$ was evaluated. It was noted that among the ethnic groups, Asians had the lowest mean $(15 \mathrm{ng} / \mathrm{mL})$, ethnicity being one of the main determinants of the variations in serum 25OHD levels (19).

In a study on construction workers in the United States a significant correlation between the sun index and serum $25 \mathrm{OHD}$ levels was found (8). In a study conducted in Hawaii $\left(20^{\circ} \mathrm{N}\right)$ by Binkley and cols. (20) with a population of young surfers, vitamin D deficiency was found in $51 \%$, using $30 \mathrm{ng} / \mathrm{mL}$ as cutoff point, despite a high rate of sun exposure in that tropical location. These results suggest that sun exposure alone is not the predominant factor in the prevention of vitamin D deficiency. Ginter and cols. (21), in a study of 224 elderly patients ( $>60$ years), showed a prevalence of vitamin D deficiency $(<30 \mathrm{ng} / \mathrm{mL}$ ) of $40 \%$ $\left(44^{\circ} \mathrm{N}\right)$. In this sample, individuals from three different ethnic groups were evaluated with no significant differences being found between them. Interestingly, another similar study in young patients (22) revealed lower serum 25OHD levels in individuals of non-European ancestry. The main predictors of vitamin D status were vitamin D intake (particularly from supplements) and skin pigmentation.

In a study comparing black and white Americans in relation to total and bioavailable serum 25OHD serum levels and to vitamin D-binding protein (which prolongs the half-life of 25OHD), it was observed that dark-skinned individuals had low levels of total 25OHD and vitamin D-binding protein, resulting in similar estimated concentrations of bioavailable $25 \mathrm{OHD}$. It is speculated that low levels of the vitamin D-binding protein may con- fer a predisposition to inadequate levels of vitamin $\mathrm{D}$ in Afro-Americans. It is proposed, therefore, that racial differences in the prevalence of genetic polymorphisms in the vitamin $\mathrm{D}$-binding protein gene provide a likely explanation for this observation. The higher prevalence in dark-skinned individuals of a polymorphism in the vitamin D-binding protein gene is associated with low serum levels of this protein, resulting in bioavailable serum $25 \mathrm{OHD}$ levels similar to those of fair-skinned individuals, despite the former having lower levels of total 25OHD (23). Gutiérrez and cols., in a study conducted in the U.S. (24), evaluated Caucasians, Hispanics and subjects of African descent and found differences in both serum 25OHD and PTH levels and in bone mineral density, suggesting that the ideal levels and action of vitamin D in the body may be individualized, depending on the ethnicity.

\section{ETHNICITY AND VITAMIN D DEFICIENCY IN BRAZIL}

In our institution a cross-sectional study (25) was conducted to assess the prevalence of vitamin $\mathrm{D}$ deficiency according to sun index and skin phototype. A large sample comprising 894 individuals older than 18 years was evaluated. The mean age was $58.15 \pm 12.08$ years, $59.1 \%$ were female and the majority $(60.6 \%)$ had a skin phototype between III and IV (the Fitzpatrick classification). The prevalence of vitamin $\mathrm{D}$ deficiency, using cut-off points for serum 25OHD levels below 20 and $30 \mathrm{ng} / \mathrm{mL}$, was $28.5 \%$ and $43.5 \%$, respectively. The mean serum $25 \mathrm{OHD}$ level was $26.06 \pm 10.37 \mathrm{ng} / \mathrm{mL}$ and the mean sun index was $5.21 \pm 4.96$ (Table 2 ).

The prevalence of vitamin $\mathrm{D}$ deficiency (serum $25 \mathrm{OHD}<30 \mathrm{ng} / \mathrm{mL})$ in those individuals with a low sun index $(<1)$ was $71.2 \%$, and in those with a higher one $(>7)$ it was $67.9 \%$. These differences were very small considering the amount of sun exposure in the 2 groups. Likewise, the differences in mean serum 25OHD levels between the 2 groups, although statistically significant ( 25.3 vs. $27.8 \mathrm{ng} / \mathrm{mL} ; \mathrm{p}=0.012)$, was small in absolute terms, considering the differences in the amount of sunlight that both groups of individuals were exposed to, demonstrating that, despite a high sun exposure in everyday life, the mean serum 25OHD concentrations were below $30 \mathrm{ng} / \mathrm{mL}$ in the vast majority of subjects (25) (Figure 3).

The prevalence of vitamin $\mathrm{D}$ deficiency among individuals with a low sun index $(<1)$ and those with a high one (> 7) ranged from 29.5 to $21.3 \%$ (considering serum $25 \mathrm{OHD}<20 \mathrm{ng} / \mathrm{mL}$ ) and from 71.2 to $67.9 \%$ (considering serum $25 \mathrm{OHD}<30 \mathrm{ng} / \mathrm{mL}$ ), both with no statistical significance $(\mathrm{p}=0.119)(25)$. 
Table 2. Prevalence of vitamin D deficiency (\%) according to sun index and skin phototype

\begin{tabular}{|c|c|c|c|c|c|c|}
\hline & \multicolumn{2}{|c|}{$<20 \mathrm{ng} / \mathrm{mL}$} & \multicolumn{2}{|c|}{$<30 \mathrm{ng} / \mathrm{mL}$} & & $p$ value \\
\hline & \multicolumn{2}{|c|}{$n=255(\%)$} & \multicolumn{2}{|c|}{$\mathrm{n}=644(\%)$} & & \\
\hline \multicolumn{7}{|c|}{ Sun index } \\
\hline $0-1$ & 46 & 29.5 & 111 & 71.2 & 156 & $p=0.119$ \\
\hline$>1-2$ & 40 & 37.0 & 86 & 79.6 & 108 & \\
\hline$>2-3$ & 46 & 33.1 & 105 & 75.5 & 139 & \\
\hline$>3-4$ & 19 & 35.8 & 41 & 77.4 & 53 & \\
\hline$>4-5$ & 22 & 28.2 & 50 & 64.1 & 78 & \\
\hline$>5-6$ & 19 & 24.1 & 60 & 75.9 & 79 & \\
\hline$>6-7$ & 12 & 29.3 & 28 & 68.3 & 41 & \\
\hline$>7$ & 51 & 21.3 & 163 & 67.9 & 240 & \\
\hline \multicolumn{7}{|c|}{ Skin phototype } \\
\hline I & 10 & 55.6 & 16 & 88.9 & 18 & $p=0.133$ \\
\hline$\|$ & 45 & 33.1 & 102 & 75.0 & 136 & \\
\hline III & 61 & 25.1 & 180 & 74.1 & 243 & \\
\hline IV & 81 & 27.1 & 207 & 69.2 & 299 & \\
\hline V & 42 & 32.1 & 95 & 72.5 & 131 & \\
\hline VI & 16 & 23.9 & 44 & 65.7 & 67 & \\
\hline
\end{tabular}

Adapted from Gondim and cols. 2013 (25).

Similarly, as shown in figure $3(\mathrm{~B})$, the prevalence of vitamin $\mathrm{D}$ deficiency $(<20 \mathrm{ng} / \mathrm{mL}$ ) was $55.6 \%$ for those with skin phototype I in comparison to $23.9 \%$ among those with skin phototype VI. Considering serum 25OHD levels below $30 \mathrm{ng} / \mathrm{mL}$, the prevalence of vitamin D deficiency was $88.9 \%$ for those individuals with skin type I, and $65.7 \%$ for those with skin type VI. These data suggest that skin tanning due to higher sun exposure was the main factor in determining the lower prevalence of vitamin $\mathrm{D}$ deficiency in individuals with a higher sun index and darker skins (25).

Most of the population (60.6\%) had a skin phototype of III or IV, and there was no statistical significance ( $\mathrm{p}=0.158)$ between mean serum 25OHD levels of those with very fair skin (type I) and those with dark skin (type VI) (25).

We also conducted a study at two beaches located on the coastline of the state of Pernambuco (latitude $8^{\circ} \mathrm{S}$ ) in order to evaluate the changes in serum $25 \mathrm{OHD}$ levels after prolonged sun exposure in 10 healthy subjects with pigmented skin due to frequent exposure to sunlight with more than $70 \%$ of body surface area exposed. Serum $25 \mathrm{OHD}$ levels increased from $22.59 \pm 5.45 \mathrm{ng} / \mathrm{mL}$ to $24.39 \pm 6.60 \mathrm{ng} / \mathrm{mL}$ after 4 hours of sunlight exposure and to $25.80 \pm 5.81 \mathrm{ng} / \mathrm{mL}$ after one week, before the next exposure. Changes in serum 25OHD levels were fewer than expected for the intensity of sun exposure, suggesting that unprotected sun exposure can be a less ap-
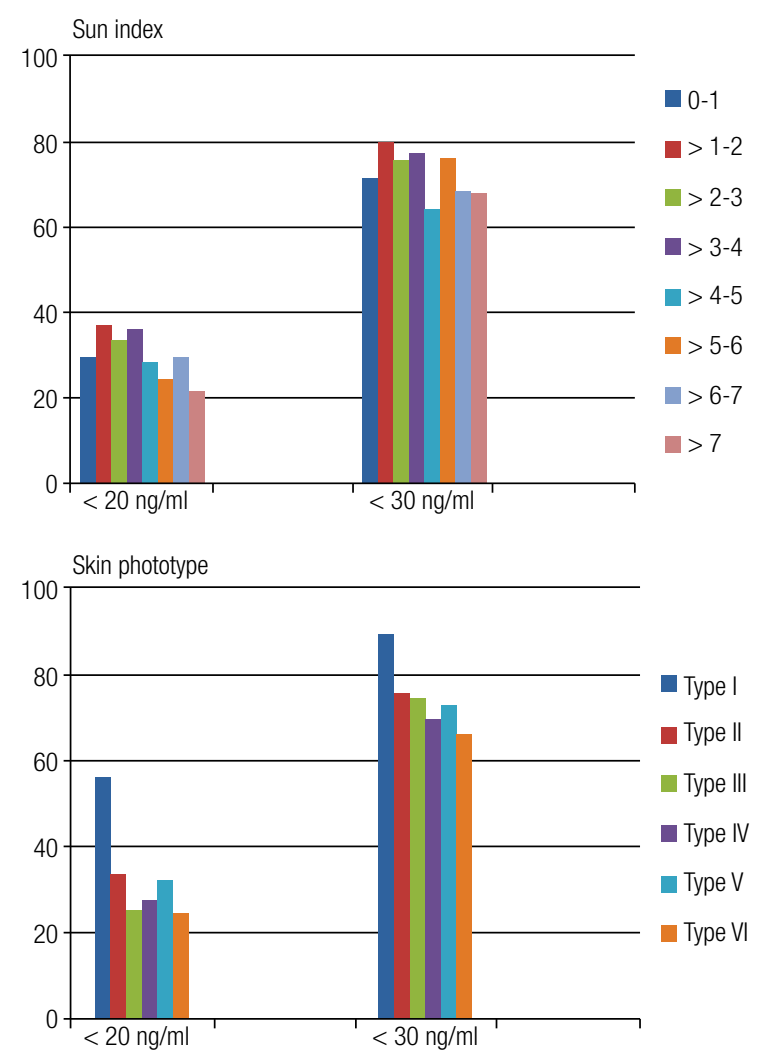

Figure 3. Distribution of vitamin D deficiency (\%) according to sun index and skin phototype.

propriate approach for correction of vitamin D deficiency than oral vitamin D supplementation (26).

In a study of 121 healthy young (mean age 24.7 years) individuals living in the city of São Paulo $\left(23^{\circ} \mathrm{S}\right)$ a positive association was shown between sun exposure and serum 25OHD levels, and individuals with low sun exposure had lower 25OHD levels than those with intermediate or high sun exposure. Mean serum 25OHD was $31.5 \mathrm{ng} /$ $\mathrm{mL}$ (27). Similarly, elderly people (mean 79.1 years) from the city of Sao Paulo showed mean serum 25OHD levels of $11.6 \mathrm{ng} / \mathrm{mL}$ during the winter, suggesting a major influence of seasonality (28), and an evaluation of 99 active elderly individuals aged 55-83 years from different ethnic backgrounds showed a mean serum $25 \mathrm{OHD}$ of $31.56 \pm$ $12.36 \mathrm{ng} / \mathrm{mL}$ in winter and $36.64 \pm 12.68 \mathrm{ng} / \mathrm{mL}$ in summer. The increase in serum $25 \mathrm{OHD}$ levels in summer occurred in white men aged 55-70 years and was not observed in adults over 71 years, suggesting that seasonal variation in serum $25 \mathrm{OHD}$ levels may be influenced by gender, ethnicity and age (12).

In another study from our institution on 284 elderly men from the city of Recife attending a primary care clinic, vitamin D deficiency (serum 25OHD levels $<20 \mathrm{ng} /$ 
$\mathrm{mL}$ ) was observed in $31.5 \%$ and insufficiency $(25 \mathrm{OHD}$ levels $<30 \mathrm{ng} / \mathrm{mL}$ ) in $66.7 \%$. There were no significant differences in the serum 25OHD levels between individuals with higher sun exposure and those with lower sun exposure. Most individuals (66.7\%) had skin phototype IV, V or VI, according to the Fitzpatrick classification (2).

In summary, regarding ethnicity, sun exposure and the differences between high and low latitudes, the data presented above suggest that in high latitude regions in which extreme skin phototypes have been compared, the prevalence of vitamin $\mathrm{D}$ deficiency is more common in people with originally darker skin who have a natural barrier to the already lower UV irradiation penetrating the skin. On the other hand, in tropical regions in which extreme skin phototypes (type I and VI) are not common, higher sun exposure rates lead to tanner skins and a lower prevalence of vitamin D deficiency. However, in those areas most individuals with high rates of daily exposure to the sun have serum $25 \mathrm{OHD}$ below $30 \mathrm{ng} / \mathrm{mL}$, suggesting that skin tanning limits the progressive rise in serum 25OHD towards optimal concentrations.

Disclosure: no potential conflict of interest relevant to this article was reported.

\section{REFERENCES}

1. Holick MF. Sunlight and vitamin D for bone health and prevention of autoimmune diseases, cancers, and cardiovascular disease. Am J Clin Nutr. 2004;80(suppl):1678S-88S.

2. Cabral MA, Borges CN, Maia JMC, Aires CAM, Bandeira F. Prevalence of vitamin $D$ deficiency during the summer and its relationship with sun exposure and skin phototype in elderly men living in the tropics. Clin Interv Aging. 2013;8:1347-51.

3. Adams JS, Huewison M. Uptodate in vitamin D. J Clin Endocrinol Metab. 2010;95:471-8.

4. Jablonski NG, Chaplin G. The evolution of human skin coloration. J Hum Evol. 2000;39:57-106.

5. Cordain L, Eaton SB, Sebastian A, Mann N, Lindeberg S, Watkins $B A$, et al. Origins and evolution of the Western diet: health implications for the 21st century. Am J Clin Nutr. 2005;81:341-54.

6. Fitzpatrick TB. The validity and practicality of sun-reactive skin types I through VI. Arch Dermatol. 1988;124(4):869-71.

7. Gilchrest BA. Sun exposure and vitamin D sufficiency. Am J Clin Nutr. 2008;570S-7S.

8. Barger-Lux MJ, Heaney RP. Effects of above average summer sun exposure on serum 25-hydroxyvitamin $D$ and calcium absorption. J Clin Endocrinol Metab. 2002;87(11):4952-6.

9. Bandeira F, Griz L, Dreyer P, Eufrazino C, Bandeira C, Freese E. Vitamin $D$ deficiency: a global perspective. Arq Bras Endocrinol Metab. 2006;50(4):640-6.

10. Holick MF. Evaluation, treatment, and prevention of vitamin D deficiency: an Endocrine Society clinical practice guideline. J Clin Endocrinol Metab. 2011;96:1911-30.

11. Rosen CJ, Abrams SA, Aloia JF, Brannon PM, Clinton SK, Durazo-Arvizu RA, et al. IOM (Institute of Medicine) Committee Members Respond to Endocrine Society Vitamin D Guideline. J Clin Endocrinol Metab. 2012;94:1146-52.
12. Maeda SS, Kunii IS, Hayashi L, Lazaretti-Castro M. Increases in summer serum 25 hydroxyvitamin D (25OHD) concentrations in elderly subjects in São Paulo, Brazil vary with age, gender and ethnicity. BMC Endocr Disord. 2010;10:12.

13. Ataie-Jafari A, Hossein-Nezha DA, Maghbooli Z, Karimi F, Rahmani $M$, Shahbazi $S$, et al. The influence of sunlight exposure on serum vitamin $\mathrm{D}$ concentration and bone turnover; a controlled clinical trial. Ir J Publ Health. 2008;1:41-8.

14. Levis $S$, Gomez A, Jimenez C, Veras L, Ma F, Lai S, et al. Vitamin D deficiency and seasonal variation in an adult South Florida population. J Clin Endocrinol Metab. 2005;90(3):1557-62.

15. Bogh MKB, Schmedes AV, Philipsen PA, Thieden E, Wulf HC. Vitamin $D$ production after UVB exposure depends on baseline vita$\min \mathrm{D}$ and total cholesterol but not on skin pigmentation. J Invest Dermatol. 2010;130:546-53.

16. Björk A, Anderson A, Johansson G, Björkegren K, Bardel A, Kristiansson $P$. Evaluation of sun holiday, diet habits, origin and other factors as determinants of vitamin D status in Swedish primary health care patients: a cross-sectional study with regression analysis of ethnic Swedish and immigrant women. BMC Fam Pract. 2013;14:129.

17. Nurbazlin $M$, CheeWS, Rokiah $P$, Tan AT, ChewYY, Nusaibah AR, et al. Effects of sun exposure on $25(\mathrm{OH})$ vitamin $D$ concentration in urban and rural women in Malaysia. Asia Pac J Clin Nutr. 2013;22(3):391-9.

18. Al-Othman A, Al-Musharaf S, Al-Daghri NM, Krishnaswamy S, Yusuf DS, Alkharfy KM, et al. Effect of physical activity and sun exposure on vitamin D status of Saudi children and adolescents. BMC Pediatr. 2012;12:92.

19. Nessvi S, Johansson L, Jopson J, Stewart A, Reeder A, McKenzie $\mathrm{R}$, et al. Association of 25-hydroxyvitamin D3 levels in adult New Zealanders with ethnicity, skin color and self-reported skin sensitivity to sun exposure. Photochem Photobiol. 2011;87:1173-8.

20. Binkley N, Novotny R, Krueger D, Kawahara T, Daida YG, Lensmeyer $\mathrm{G}$, et al. Low vitamin $\mathrm{D}$ status despite abundant sun exposure. J Clin Endocrinol Metab. 2007;92(6):2130-5.

21. Ginter JK, Krithika S, Gozdzik A, Hanwell H, Whiting S, Parra EJ. Vitamin $D$ status of older adults of diverse ancestry living in the greater Toronto area. BMC Geriatr. 2013;13(1):66.

22. Gozdzik A, Barta JL, Weir A, Cole DEC, Vieth R, Whiting SJ, et al. Serum 25-hydroxyvitamin $D$ concentrations fluctuate seasonally in young adults of diverse ancestry living in Toronto. J Nutr. 2010;140:2213-20.

23. Powe CE, Evans MK, Wenger J, Zonderman AB, Berg AH, Nalls $M$, et al. Vitamin D-binding protein and vitamin D status of black Americans and white Americans. N Engl J Med. 2013;369:1991-2000.

24. Gutiérrez OM, FarwelL WR, Kermah D, Taylor EN. Racial differences in the relationship between vitamin $\mathrm{D}$, bone mineral density, and parathyroid hormone in the National Health and Nutrition Examination Survey. Osteoporos Int. 2011;22(6):1745-53.

25. Azevedo MS, Correia A, Pimentel L, Bandeira F. Serum 25-hydroxyvitamin $D$, skin phototype, sun exposure and the metabolic risk in a large sample of subjects living in the tropics. American Society for Bone and Mineral Research Annual Meeting. 2014;SU0329.

26. Carvalho EKB, Griz L, Fontele T, Accioly LV, Melo AA, Amaral LMB, et al. Serum $250 H D$ changes following high rates of sun exposure in young subjects with pigmented skin living in the tropics. Clin Exper Med Sci. 2013;1(8):363-71.

27. Maeda SS, Kunii IS, Hayashi L, Lazaretti-Castro M. The effect of sun exposure on 25-hydroxyvitamin $D$ concentrations in young healthy subjects living in the city of São Paulo, Brazil. Braz J Med Biol Res. 2007; 40(12):1653-9.

28. Saraiva GL, Cendoroglo MS, Ramos LR, Araujo LM, Vieira JG, Kunii I, et al. Influence of ultraviolet radiation on the production of 25 hydroxyvitamin $D$ in the elderly population in the city of São Paulo (23 degrees 34'S), Brazil. Osteoporos Int. 2005;16:1649-54. 